\title{
原発巣不明の腰部放線状菌症について
}

\author{
熊本大学医学部 整形外科教室 高 浜 辰 生
(任
}

\section{A Case of Actinomycosis on the Waist Which Primary Focus is Unknown}

By

\section{T. Takahama}

Department of Orthopaedic Surgery, Kumamoto University, School of Medicine.

\section{はしがき}

放線状菌症は放線状菌によつて惹起される人類, 牛, 馬, 豚, 羊, 猫等にくる一種の化澧性, 内芽性炎症に属す るものである。その主要なる病変は一種特有の顆粒状 体, 所謂, 放線状菌塊を混ずる膿汁の形成, 組織の破 壊, 肉芽組織の新生果ては瘦孔形成による他臟器との 癒着等である。放線状菌は 1845 年，V. Langenbeck が脊椎カリエス様変化を呈する患者に打いて発見した と云われているが, 当時はとの病原性とか菌種とか詳 細に関しては不明であつた。1878 年, J. Israel はこれ が真の菌種なることを確認し，人類に対して病原性を 有することを証明した。その后, Israel, Bostroem, 等は人間の放線状菌症について研究し, 本邦に打いて は塩田教授の広汎な研究業績がある。本邦に扣いてる 稀な疾患ではないが臨林的に霣々誤診を招くことがあ る。放線状菌の感染は普通該菌が異物に附着し，これ が体内に提取され, 主として呼吸器, 消化器に固有の 病変を起するのとされている。

私は今回永い間不明熱として取り扱われ，診断の不 明であつた患者で発症 1 年で左側腰部に異常感, 1 年 4 ケ月で左側腰部に腫瘤を形成し，その睡瘤の切開撜 爬により診断の確定した原発巣不明の腰部放線状菌症 を経験したのでこつに報告する。

\section{症 例}

患者は 23 才の男子, 職業は農業に関係のない無職 で, 父の職業は医師である。

家族歴 特記すべき事項なし。

既往歴 幼時急性中耳炎, 8 才の時赫浰。

本症の感染機転に関しては何ら知る事は出来ない。

\section{現病歴}

昭和 30 年 8 月頃より $37^{\circ} \mathrm{C}$ 乃至 $39^{\circ} \mathrm{C}$ に達する熱が
弛張し始め, 同年 10 月 肺結核を疑い胸部のレントゲ ン検査を受けたが異常を認めなかつた。然しその時の 血沈值は 1 時間 $135 \mathrm{~mm}$ であつた。一応結核症を疑つ て, ストレプトマイシン $5 \mathrm{~g}$ ， パス，ヒドラジッドを 10 日間続けたが全然効果を認めず中止したと，いつ ている。昭和 30 年 11 月に本学内科を訪れ精密検査を 受けたが，所謂不明熱と云われた。その時も血沈值は 1 時間 $110 \mathrm{~mm}$ で血波值の異常六進が認められ, 白血 球数は 14,200 で細胞分類ではリンパ球の隇少があつ た。患者は家庭に打いて油性ペニシリンを 1 . 日 30 万 単位を持続的に注射したが効果なくその間オーレオマ イシンも $10 \mathrm{~g}$ 服用したが著効を認めることは出来な かつた。昭和 31 年 7 月頃から左側腰部より左側下肢 にかけて時々神経痛様の疼痛あり，8 月頃より左側腰 部に異常感, 緊張感を覚兄, 昭和 32 年 1 月になると 左側腰部に手掌大の腫瘫を形成し, 当科の治潦を求め た。当科では腰椎カリエスの疑いで入院させ検査を行 つた。

\section{入院時所見}

身艮, 骨骼普通, 栄養稍々不良, 顔面貧血性顔貌, 体温は $37^{\circ} \mathrm{C}$ 乃至 $39^{\circ} \mathrm{C}$ に及ぶ弛張熱を呈していた。

\section{自觉症}

賀血のためと思われる体動時心悸充進あり。

\section{現 症}

顔貌は蒼白で潑刺さを欠き眼臉結膜は資血性, 扁桃 腺, 胸部に異常を認めず背椎は屚平で胸椎の後秒, 腰 椎の前彎の隇少を見る。運動障碍は腰椎に軽度に存在 し, 脊椎の前方屈曲, 後方伸展に際して左側腰部より 左側下肢にかけての疼痛あり。ラセーグ氏症候は左側 $80^{\circ}$ にて陽性。脊椎に自発痛, 㠲打痛及び压痛なく, 左側プチー氏三角部より稍々上内側に手掌大の睡瘤が 
存し被覆せる皮圈は赤橴色儿着色し，周围は板状硬結 に近い硬結で中心部は瑱化して仮性波動を呈す。

\section{臨林検查成績}

試験穿刺により澧汁なく壊死様物筫が極めて少荲認 められるのみで, 腫痹には局所熱感及び区痛めり，血沈

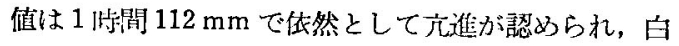
血球数は 21,000で細胞分類では好中多核白血球 $79 \%$,

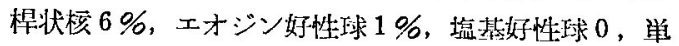
核球 $3 \%$,リンパ球 $11 \%$ でリンハ球隇少を喼める。 赫血球数は 319 万血他素 $60 \%$, 尿便に巽常なく, 感 觉障碍もない。

\section{レントゲン写寒所見}

第 2 腰椎の左側の椎马根部及び椎体に不鳘明乍ら, 軽度の皮壊像を見る他，著变は認められなかつた。

\section{手術所見}

睡膚を切開すると，灰白色及び緑出の多数のドルー ゼを発見し，大きさは粟粒大より帽針稫大に及び細菌 学的检查により坟線状菌を発見し故線状菌症なること を椎定した。尚霆孔は左側の晹骨の才に们い晹骨の一 部は侵蝕されているが敫部には放線状菌症による定型 的な病変は認めなかつた。

者 按

本症において第 2 腰椎の左側の椎弓根部及び椎体の 不鮮明な破壊像は，本症がワ氏反底除性及び結楅菌培 䍧除性なことから，この変化は故線状菌症による病変 と思われる。故線状菌症に执いては㳄部組織の泳潤が 強いため、レントダン写真で除影が明榷にあらわれな いものと思われる。!来枚線状菌は职蔀組織を好んで 冒すが骨を冒すことは稀である。脊椎を冒すことは極 めて稀で本邦では肺より転移した脊椎の坆線状菌症に ついて天児教授の報告のある他，同様な報告を散見す るが原発性に現われたのは一例もない。普通故線状䔉 は土腔から侵大するものが大多数とされ，その病变は 伝進性に应大するものであり，血行性転移及びリンパ 行性転移は少いとされている。本例に执いては，他の

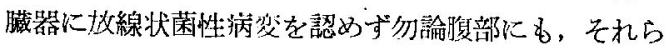
しき所見を認めない。そこで第 2 腰椎の病変が何処か ら来たか，感染径降は不明であるが考え得る感染径路 に4つある。

第 1 は経気道的に肺に達し，これより血行性に転移 を起したという考え方であるが，これは肺の所胃がな いことから否定出来る。

第 2 に羞桃線からの血行性転移であるが，前病症に す䡢桃線炎の所見はない。

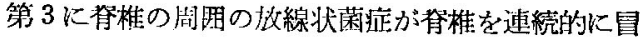
す場合である。然し腹部荿器はじめ腰椎の凬围に明礁 な所見が得られていない。

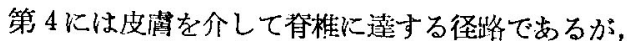
本症では，か」る径路を肯定するだけの積極的な既往 は認めていない。

以上考按するに，その可能性からは腸管か源発巣々 考觉るのが最も蓋然性が大考兄られるけれ共確定的 なことは不明である。

\section{治療及び予后}

放線状菌症の治潦であるが最近化学潦法の進少によ り治痦淬は以前に比較すると向上した様である。本症 は家庭に捺いて油性ペニシリン 30 万単位を長期間注 射していたが効果なく，当科儿て睡瘤の切開提爬后へ ニシリンを1日90万単位及びオーレオマイシン1日 $1 \mathrm{~g}$ 投与した処経過は極めて息好である。

\section{結 語}

私は今回侵入門戸不明の腰部放線状菌症を経験し第 二腰椎の左側の推弓根部及び椎体に不鮮明乍ら軽い破 壊像を認め, 左側腰部に発生せる睡瘤の切開提爬后一 ニシリンの大量注射と，オーレオマイシンの投与によ り軽快也しめたので、こつに報告した。

（終りに御指導，御校閲下さいました玉井教授に深扬 致します)

\section{主 要 交 献}

1. 梶谷：日外会誌， 42 回， 3 号

2. 沓掛：海軍医誌， 20 巻， 1 号

3. 天览：儖林之研究, 24 春, 9 号

4. Bostroem, Ziegbr' Beiträge zur pathologi schen Anatomie. $1891 \mathrm{Bd} .9$

5 . 浜崎：医 学, 4 拳, 5 号

6 。渡辽：䧗林外科, 7 巻, 7 号

7. 奥島：臨状外科, 7 巻, 7 号

8. 中村：グレンツゲビート， 4 巻

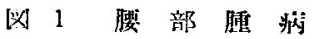

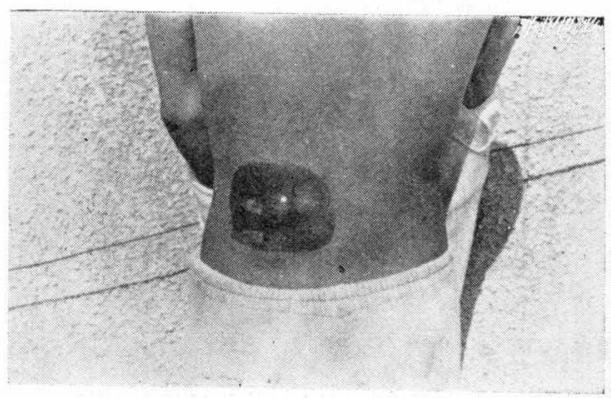


汹2 腰椎レントゲン

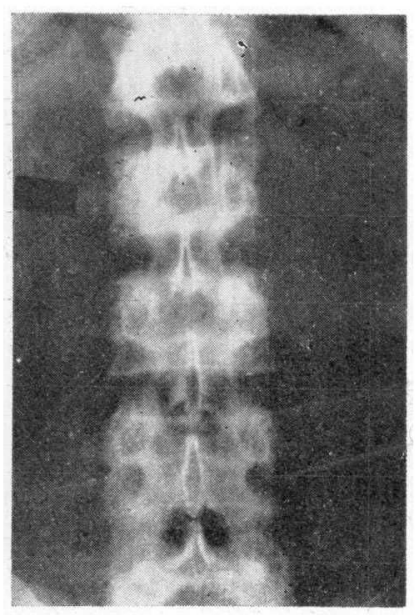

兴 3 レントゲン畧兴

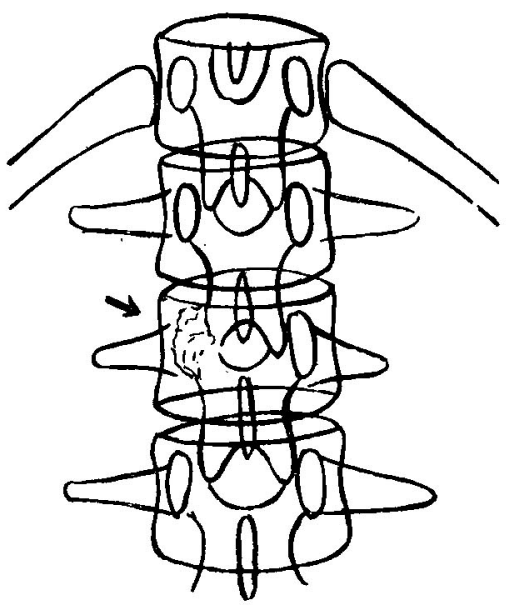

\section{肩胛上腕神経症候群の発症に関する新知見}

$\begin{array}{lllll}\text { 九州厚生年金病院 整形外科 } & \text { 岩 } & \text { 永 } & & \text { 崇 } \\ & \text { 城 } & \text { 間 } & \text { 寅 } & \text { 夫 } \\ & \text { 大 } & \text { 山 } & \text { 郁 } & \text { 雄 }\end{array}$
A View of the Omobrachial Synodrom
By
T. Iwanaga, T. Shiroma and I. Öyama
Orthopedic Clinic Kyushu
Welfare Pension Hospital

层及び上肢指は各種の原因で起り，実際には原因の 不詳な终痛が少くない。之等の例に対して吾々は頸部

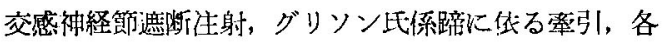

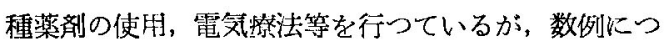
いては前斜有筋断䉼術を行い相当の効果を收めた。

症例 1 ; 上肢運動性は良好であるが，居甲部より上 肢の疼甬があり，右第 7 頸椎の横突起が大きく、アド ソン血管試珻は陽性，保存的治潦で効果なく，前斜角

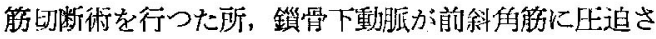
れ瘾着して居た。又腕神経叢は所謂尾方型であつた。 術后疼痛は消失したが，術后 10 日日上り側頸部より

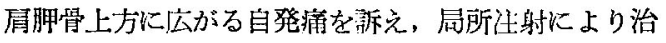
療した。

症例 2 : 局甲部及上腕慂あり，保存的治潦によつて

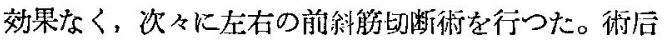

4 日目より，右肩答部に自発痛を訴光た。

症例 3：1 年丮前加肩上り上肢痛あり。保存的治 潦で治療せず，前斜角筋切断術に依つて“薄皮”を虽 いだ様汇軽くなつた。術后 8 日目より局甲部の自発薄 が起つた。又右側は 9 日目上り該部に重感と自発痛が 起つたが，局注等で治癒した。

症例 4 : 握力の隇退等を訴えて来院したもので、 エログラフィーを行つたが変化を認めず，亦保存的簝 法が奏效しないので，前斜任筋切㯕術を行つた。術后 上肢の学上が容易になつた他に上肢知覚障害が消失し たが，書痓は残存した。本例は術后の周甲痛は表れな かつた。

症例 5：3 ケ月前上り房胛部疼痛めり，右胸鎖関節 亚脱臼ありと云はれて，電気治澺及びその他の治璄を らけて居たが軽快しなかつた。前斜伯筋断断術を行つ 